\title{
8
}
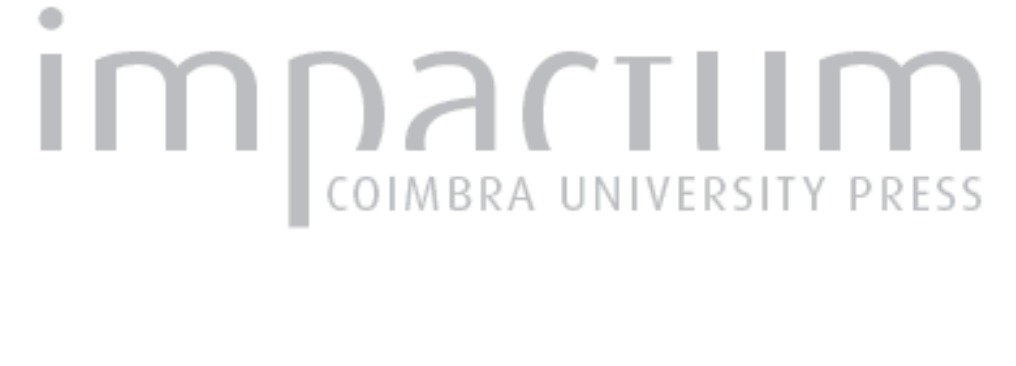

\section{Linguagem política e leituras do Contrato Social nos alvores da Revolução Liberal em Portugal}

\author{
Autor(es): $\quad$ Araújo, Ana Cristina \\ Publicado por: Centro de História da Sociedade e da Cultura \\ URL \\ persistente: \\ URI:http://hdl.handle.net/10316.2/39393 \\ DOI: \\ DOI:http://dx.doi.org/10.14195/1645-2259_13_11
}

Accessed : $\quad$ 26-Apr-2023 15:14:15

A navegação consulta e descarregamento dos títulos inseridos nas Bibliotecas Digitais UC Digitalis, UC Pombalina e UC Impactum, pressupõem a aceitação plena e sem reservas dos Termos e Condições de Uso destas Bibliotecas Digitais, disponíveis em https://digitalis.uc.pt/pt-pt/termos.

Conforme exposto nos referidos Termos e Condições de Uso, o descarregamento de títulos de acesso restrito requer uma licença válida de autorização devendo o utilizador aceder ao(s) documento(s) a partir de um endereço de IP da instituição detentora da supramencionada licença.

Ao utilizador é apenas permitido o descarregamento para uso pessoal, pelo que o emprego do(s) título(s) descarregado(s) para outro fim, designadamente comercial, carece de autorização do respetivo autor ou editor da obra.

Na medida em que todas as obras da UC Digitalis se encontram protegidas pelo Código do Direito de Autor e Direitos Conexos e demais legislação aplicável, toda a cópia, parcial ou total, deste documento, nos casos em que é legalmente admitida, deverá conter ou fazer-se acompanhar por este aviso.

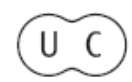



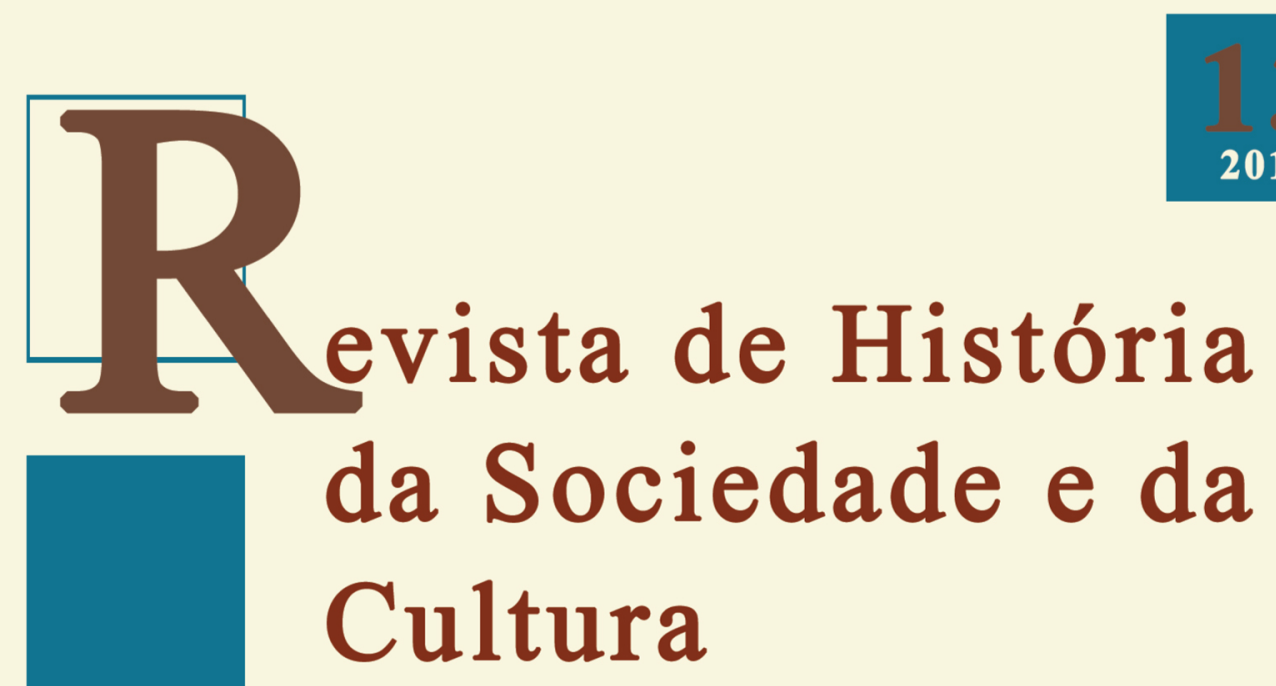

2013

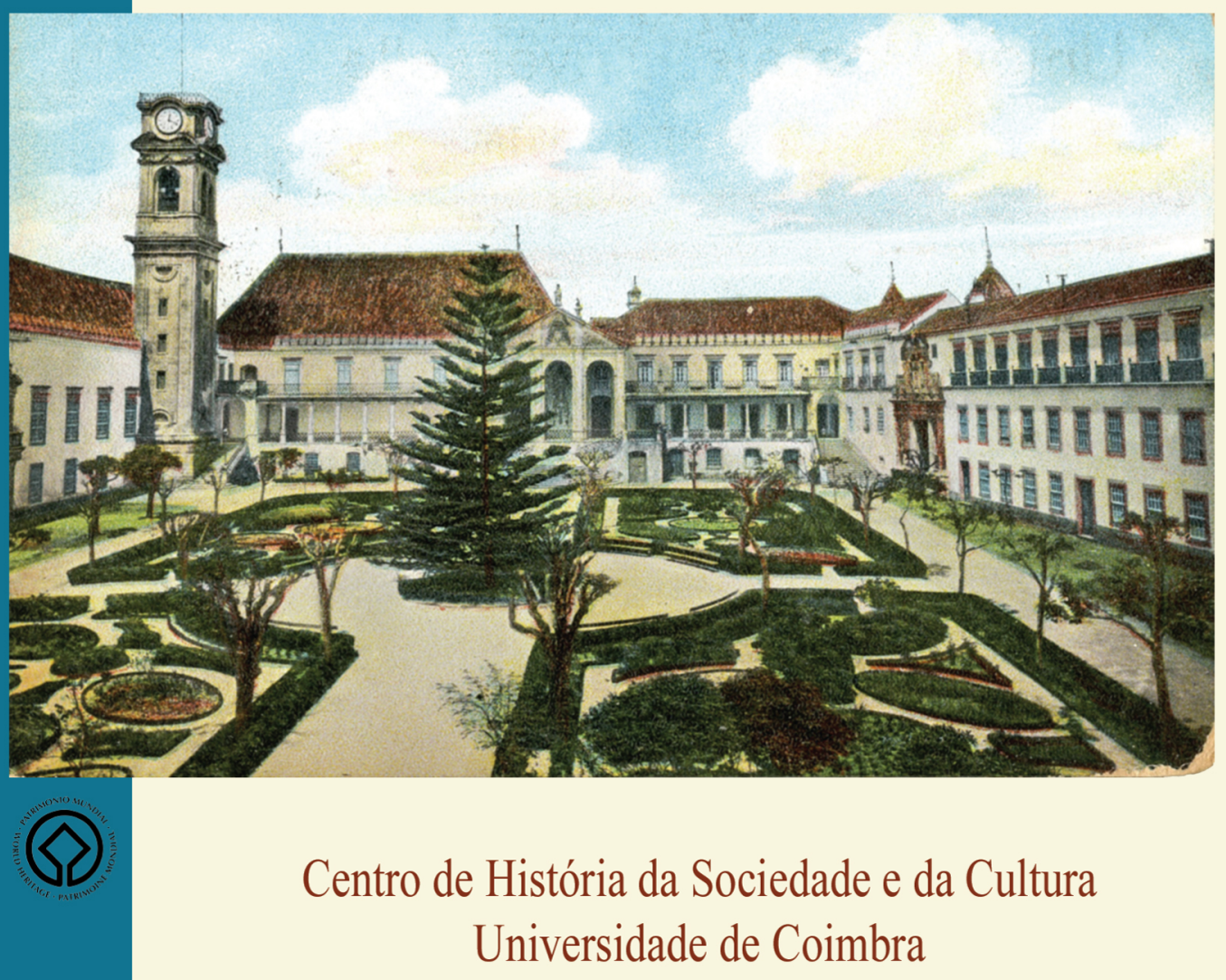

Coimbra 


\title{
Linguagem Política e Leituras do Contrato Social nos alvores da Revolução Liberal em Portugal*
}

\author{
Ana Cristina Araújo \\ Professora da Faculdade de Letras da Universidade de Coimbra \\ Investigadora integrada do Centro de História da Sociedade e da Cultura \\ araujo.anacris@sapo.pt \\ Texto recebido em /Text submitted on: 07/06/2013 \\ Texto aprovado em /Text approved on: 08/11/2013
}

Resumo/Abstract:

O vocabulário político que impulsionou a expansão editorial e periódica em Portugal, em finais do século XVIII, tem subjacente a divulgação do pensamento de Jean-Jacques Rousseau. Depois da Revolução de 1820, o Contrato Social (1762) foi traduzido para português e conheceu três edições no espaço de um ano.

Os publicistas liberais e os escritores mais acutilantes inspiraram-se diretamente em Jean-Jacques Rousseau para sublinharem a importância dos direitos do homem e do cidadão e as vantagens do pacto social e das leis. Por outro lado, as controvérsias em torno dos conceitos de vontade geral, opinião pública e religião civil evidenciam os limites colocados à aceitação, com reservas, da teoria política do Contrato Social. Ainda assim, para reforçar o lado prático de adesão afetiva à causa liberal, a sociabilidade política, assente na observância sagrada da lei e no compromisso do contrato social, confere um papel primacial à catequese revolucionária e à educação cívica do povo.

Jean-Jacques Rousseau philosophy was the driving force behind the political vocabulary that fostered the editorial and periodical publishing burst in Portugal, in the end of XVIII century. After 1820 Revolution, the Social Contract (1762) was translated into Portuguese and published in three different editions within one year.

Liberals and activist writers found their direct inspiration in Jean-Jacques Rousseau to highlight the importance of civil and human rights, as well as the advantages of the social pact and law. On the other hand, controversy around concepts of general will, public opinion and civil religion show limits to acceptance, although with restrictions, of the political theory behind the Social Contract. Even though political sociability - based in a sacred obedience to the law and commitment to social contract - puts revolutionary catechism and civic education of the people in a privileged role to strengthen the practical aspects of affective-based adhesion to the liberal cause.

Palavras chave/Keywords:

Contrato Social; Catecismos Políticos; Opinião Pública; Patriotismo.

Social Contract; Political Catechisms; Public Opinion; Patriotism.

* Este artigo aprofunda e amplia a temática da comunicação que apresentei ao Colóquio Jean-Jacques Rousseau em debate. Sociedade, Política e Estado. Trezentos anos depois, realizado na Faculdade de Letras da Universidade de Coimbra, a 7 de Dezembro de 2012. 
No século das Luzes, Jean-Jacques Rousseau radicaliza, com argumentos filosóficos, o campo de enunciação da teoria política. No Contrato Social (1762), instrumento fundamental para a compreensão prospectiva do pensamento político contemporâneo, explicita o que entende por "princípios do direito político" e articula esses princípios da ciência da legislação com as instituições que, em abstracto, asseguram a criação e conservação de sociedades politicamente organizadas. Em termos filosóficos, os limites da vida política demarcam, no seu pensamento, as possibilidades de renovação da legitimidade dos governos. Dito de outro modo, a crítica radical à sociedade, em nome da natureza e do direito natural, suporta o carácter contratual e voluntário do pacto de associação política, forjado artificialmente para garantir a conservação e proteção do indivíduo e, simultaneamente, preservar intacta a sua liberdade original, problema central do direito político.

Especificando, segundo Rousseau, a comunidade política assenta numa convenção voluntária que em si mesma encerra uma razão forte para gerar obediência na sociedade civil. O contrato social, que define os termos desta convenção, acarreta, assim, uma alienação total de todos os direitos do indivíduo no estado natural. Desta alienação resulta a formação do corpo político, encarado como um todo, e dele emerge um poder soberano que consente e respeita a vontade geral que o gerou. Logo, a legislação e os actos de soberania só são por definição legítimos se emanarem da vontade geral, desse "eu comum" que subsume livremente o interesse particular na conveniência do todo social e no bem da comunidade.

Os especialistas da obra política de Jean-Jacques Rousseau tem sublinhado a importância da distinção entre os princípios filosóficos que explicam a natureza da lei e as regras da prudência política que justificam o modo da sua aplicação ${ }^{1}$. A natureza da lei, que exige uma alienação total dos direitos naturais, torna possível a obediência livremente consentida à norma civil imposta pelo Estado. Nesta perspectiva, pode dizer-se que Rousseau equaciona a questão da natureza da lei em função da sua finalidade.

1 Problemática tratada por COBBAN, Alfred-Rousseau and the Modern State. Londres: Shoe String Press, 1961 ( $1^{\text {a }}$ ed. 1934); DERATHÉ, Robert Jean-Jacques Rousseau et la science politique de son temps. Paris: J. Vrin, 1995; e, especialmente, por MASTERS, Roger D. - La Philosophie politique de Rousseau (trad. Gerard Colonna d'Istria \& Jean-Pierre Guillot). Paris: ENS Éditions, 2002 (1ª ed. 1968). 
Na sociedade civil, a vigência e obediência à lei operam-se no quadro de determinadas formas de governo. Nos livros III e IV do Contrato Social, consagrados à "forma do governo", Rousseau desenvolve a questão do regime particular que convém a uma determinada sociedade, com o objectivo de salientar os meios utilizados para reforçar "a Constituição do Estado", isto é, os princípios considerados fundamentais para a manutenção de uma ordem estável. Portanto, a intenção de Rousseau não é apenas a de descrever o estabelecimento da sociedade política, mas a de fundar em razões justas e aceitáveis a obediência legítima a um poder que emana da vontade geral.

Sem pretender sustentar qualquer apropriação doutrinária da obra do filósofo genebrino - não é esse o nosso propósito -, importa ressaltar que Rousseau, em carta ao seu editor, considera que o conteúdo do Contrato Social é "une matière difficile, faite pour un petit nombre de lecteurs"2. Consciente ou não do futuro de um livro que, pela intensa polémica que logo suscitou, parecia destinado a perdurar, o filósofo não oculta, todavia, a dificuldade da matéria nele tratada. Depois daquele primeiro juízo, Rousseau, confrontado com a popularidade dos seus escritos, procura preservar a unidade do seu sistema filosófico e salvar a singularidade dos conceitos que desenvolvera em matéria de política e educação. Nos Dialogues, dá voz a um interlocutor imaginário, de naturalidade francesa, que procura contrariar interpretações supostamente erróneas e abusivas da obra de Rousseau e que aponta para uma releitura, ou melhor, para uma "segunda leitura" do seu pensamento filosófico. Original no método que engendra para impor uma interpretação, o autor ousa desta forma sobrepor o seu juízo ao livre entendimento do leitor. No essencial, converte o ponto de chegada do seu pensamento - exposto em l'Émile e no Contrat Social, ambos editados em 1762 - na razão axial do seu discurso filosófico: “J'avais senti [diz o interlocutor francês] dès ma première lecture que ses écrits marchaient dans un certain ordre qu'il fallait trouver pour suivre la chaîne de leur contenu. J'avais cru que cet ordre était rétrograde à celui de leur publication, et que l'auteur remontant de principe en principes n'avait atteint les premiers que dans les derniers écrits. Il fallait donc pour marcher par synthèse commencer

2 Carta de Jean-Jacques Rousseau a Rey, datada de 4 de Abril de 1762, apud MASTERS, Roger D. - La Philosophie politique de Rousseau. Paris: ENS Éditions, 2002, p. 355. 
par ceux-ci, et c'est ce que je fis en m'attahchant d'abord à l'Émile par lequel il a fini, les deux autres écrits qu'il a publiés depuis ne faisant plus partie de son système, et n'étant destinés qu'à la défense personelle de sa patrie et de son honneur."3

Esta proposta de releitura encerra uma classificação e aponta, de forma inequívoca, para um esquema compreensivo global da obra do filósofo de Genebra, sendo intencionalmente escrita para uso e meditação dos seus contemporâneos. Ainda assim, no século XVIII, em países como Portugal, em que a censura estatal é forte mas não inexpugnável, o pensamento filosófico e político de Rousseau não pode dissociar-se das leituras antitéticas produzidas por censores, leitores, divulgadores e tradutores. Nesta perspetiva, ser contemporâneo de Rousseau significava ter notícia do rasto polémico das suas ideias e implicava, também, aceder ao julgamento crítico da sua obra.

Apesar das conhecidas restrições de acesso às novidades literárias da Europa das Luzes, a introdução precoce dos mais importantes títulos de Jean-Jacques Rousseau em Portugal não deixa de ser surpreendente. Nos anos 60 e 70 do século XVIII, textos fundamentais como o Discours sur les sciences et les arts (1750), o Discours sur l'origine et les fondements de l'inégalité parmi les hommes (1755), Émile ou de l'Éducation (1762), Du Contrat Social (1762), e uma série de compilações, saídas de diferentes prelos europeus entre 1763 e 1796, constam de importantes catálogos de livreiros e estão presentes em inúmeras bibliotecas públicas e particulares portuguesas. $^{4}$

\section{Controvérsias em torno de Jean-Jacques Rousseau}

O contexto repressivo e censório em que ocorre o persistente processo de difusão das obras do filósofo de Genebra põe à prova as competências

3 Jean-Jacques Rousseau - Oeuvres Complètes, Dialogues, III, vol. I. Paris: Gallimard, Bibliothèque de la Pléiade, 1964, p. 932. As duas obras posteriores ao Contrat Social e a l'Émile que surgem referenciadas no texto são, respectivamente, as Lettres écrites de la Montagne e a Lettre à M. Christophe de Beaumont.

4 MACHADO, Fernando Augusto - Rousseau em Portugal. Da clandestinidade setecentista à legalidade vintista. Porto: Campo das Letras, 2000, p. 183-186. 
linguísticas em francês e inglês das elites cultas portuguesas ${ }^{5}$, mas também evidencia a necessidade sentida por uma parte desses agentes culturais de refutação pública das teses de Rousseau, em matérias de religião e política. As mais significativas tomadas de posição pública contra Jean-Jacques Rousseau configuram, assim, a necessidade de uma clara demarcação crítica e surgem, de facto, na sequência de processos inquisitoriais célebres, como o que o que atingiu o matemático, poeta e filósofo José Anastácio da Cunha $(1778)^{6}$. Do mesmo o modo, a leitura da obra do filósofo de Genebra permanece como móbil central de acusação no auto da devassa de 1781, que sentenciou, como ativos divulgadores da obra de Rousseau e perigosos livres-pensadores, vários jovens estudantes da Universidade de Coimbra, naturais do reino e do Brasil'.

Em articulação com a repressão inquisitorial e policial, sabe-se que a vulgarização dos ideais de Rousseau foi dinamizada a partir de pequenos círculos de leitura organizados a partir do núcleo militar de Valença do Minho, onde pontuam José Anastácio da Cunha e Diogo Ferrier, do plural universo académico de Coimbra, em que avultam vivas manifestações de contestação juvenil e de outros focos de livre pensamento que irradiam no Porto, em Lamego e em Lisboa. Na capital portuguesa, os sequazes do "filosofismo irreligioso", de inspiração rousseauniana, atingem maior projeção social. Fazem-se notar nos salões eruditos e nas tertúlias de café, mas também animam as desavenças literárias que minam o convívio intelectual da casa do Risco da Ribeira das Naus e atingem as redes de sociabilidade tecidas no seio da Real Academia das Ciências de Lisboa ${ }^{8}$.

Em paralelo, e de forma mais ou menos anónima, outros divulgadores fizeram correr rios de tinta em polémicas espúrias, norteadas por conceitos, ideias e aspirações de matriz rousseauniana, como a que ocorreu, nos anos

5 ARAÚJO, Ana Cristina - Modalidades de Leitura das Luzes no tempo de Pombal. Revista de História - Centro de História da Universidade do Porto. X (1990) 105-127.

6 FERRO, João Pedro (ed.) - O processo de José Anastácio da Cunha na Inquisição de Coimbra (1778). Lisboa: Palas, 1987.

7 RAMOS, Luís A. de Oliveira - Sobre os ilustrados da Academia de Coimbra. Estudos de Homenagem a João Francisco Marques. Porto: Faculdade de Letras, 2001, vol. II, p. 311-326.

8 RAMOS, Luís A. de Oliveira - Sob o Signo das Luzes. Lisboa: Imprensa Nacional-Casa da Moeda, 1988, p. 138-141. 
oitenta, com a publicação e refutação pública da obra intitulada Filósofo Solitário. O autor tradutor deste texto de combate retoma a crítica, lançada por Jean-Jacques Rousseau, ao modo de vida urbano no século XVIII, nomeadamente quando aborda a corrupção introduzida pelo luxo, pelos espetáculos e pela moda. Em contrapartida, sublinha a associação entre a virtude e a liberdade do homem, sustentando que a filosofia é filha da liberdade e só esta impede a escravidão social ${ }^{9}$.

Com o debate polarizado em torno das questões da sociabilidade e da religião, uma das mais significativas obras francesas de refutação sistemática do pensamento do mais temido dos filósofos do século acabaria por ser publicada, em Portugal, em 1787. Trata-se de O Deismo Refutado por si mesmo, ou exame dos principios de incredulidade, espalhados nas differentes obras de João Jacques Rousseau, em forma de cartas, do abade Bergier, traduzido e dado à estampa por Francisco Coelho da Silva, vinte e dois anos depois da $1^{\mathrm{a}}$ edição francesa. No prólogo que acompanha a tradução, o editor português não escamoteia a geral aceitação e popularidade do pensamento do autor de Émile, esforçando-se por tornar percetíveis a todo o género de leitores as ideias que são objeto de crítica.

À medida que proliferam as transgressões ocultas e as derivas clandestinas de seguidores ocultos, como a Marquesa de Alorna, e de críticos contundentes do filósofo, como Bento José de Sousa Farinha, a imprensa periódica contribui, igualmente, para mediatização progressiva do ideário político do autor do Contrat Social ${ }^{10}$. Antes e depois da Revolução Francesa, Rousseau torna-se objecto recorrente de notícia. O Jornal Enciclopédico, em artigo de Maio de 1789, considera que o "merecimento próprio" de Rousseau em matéria moral "é sobejo para conciliar a aprovação e estímulo de todos os inteligentes" ${ }^{11}$. Um mês depois, uma elogiosa transcrição retirada da introdução de Mercier às Oeuvres Complètes (1788) de Rousseau tornava mais atrativa esta edição que, apesar de proibida, era publicitada para subscrição. Este volte de face em relação ao autor do Contrato Social

9 ARAÚJO, Ana Cristina - O Filósofo Solitário e a esfera pública das Luzes. Estudos de Homenagem a L. A. de Oliveira Ramos. Porto: Faculdade de Letras, 2004, vol. I, p. 201.

${ }^{10}$ ARAÚJO, Ana Cristina - A Cultura das Luzes em Portugal. Temas e Problemas. Lisboa: Livros Horizonte, 2003, p. 84 e ss.

${ }^{11}$ Jornal Encyclopedico, Maio-1789, vol. V, p. 296. 
patenteia-se, sem reservas, no comentário feito à segunda edição do livro de Schwarz, Reflexions sur l'Esclavage des Negres (1788). A notícia desta obra surge envolta numa velada crítica dirigida aos que atacam os 'espíritos quiméricos' e defendem os 'Direitos do Homem'. O articulista do jornal louva, assim, os sequazes do pensamento de Jean-Jacques Rousseau, assumindo a defesa da liberdade e dos direitos dos cidadãos ${ }^{12}$.

Ao mesmo tempo, no campo da pedagogia, Émile ou de l'Éducation é motivo de viva controvérsia. Em Janeiro de 1792, o redator do Jornal Enciclopédico admite não ser razoável "seguir à risca" o sistema de Rousseau, mas acrescenta que "sempre que houver ocasião de o pôr em prática sem dificuldade se tirará dele proveito". A fratura crítica provocada por esta obra, que, ao contrário de outros títulos de Rousseau, não conheceu qualquer tradução integral no nosso país, no século XIX, é atenuada pela publicação, em 1816, no periódico o Investigador Portuguez, de um esclarecedor texto de crítica e comentário, O Homem singular ou Emilio no mundo, de Augusto Lafontaine, publicado também, autonomamente, em 1822. Antes da revolução portuguesa de 1820, Francisco Freire de Carvalho, professor do Colégio Real dos Nobres, tenta ainda traduzir o Contrat Social, mas é dissuadido de o fazer pela Junta Censória ${ }^{13}$.

\section{Novos códigos de linguagem política}

O juízo crítico suscitado pelas ideias de Rousseau acentuou-se depois da Revolução Francesa. Mais concretamente, a luta em prol da emancipação do povo permaneceu como farol de esperança para os resistentes portugueses que procuraram ligar o sentimento de lealdade e de sacrifício pela pátria, no período das invasões francesas (1807-1811), à observância da liberdade. Neste quadro, importa considerar as referências ideológicas de que partem João Bernardo da Rocha Loureiro e Pato Moniz, redatores do primeiro jornal liberal português editado no reino, O Correio da Península ou Novo

\footnotetext{
12 Jornal Encyclopedico, Maio-1789, vol. V, p. 41.

${ }^{13}$ MACHADO, Fernando Augusto - Almeida Garrett e a introdução do pensamento educacional de Rousseau em Portugal. Porto: Asa, 1993, p. 111.
} 
Telégrafo (1809-1810). Neste jornal, os câmbios da convenção linguística denotam os novos usos da linguagem política e o seu impacto na sociedade.

A circulação de textos de propaganda tornara-se então mais intensa à escala da Península Ibérica. O Correio da Península divulga extratos do Semanario Patriotico, do Diario de Badajoz e de outras folhas periódicas. A guerra movida pela imprensa, considerada necessária e justa, visava inflamar os ânimos das gentes lusas, ou, como então se dizia, mobilizar o "clamor da pátria" para a defesa da nação abatida, conforme escreve Pato de Moniz no artigo "Patriotismo", publicado no Correio da Península ${ }^{14}$. Em Janeiro de 1810, aquele redator assinava, no referido periódico, um longo artigo intitulado " A Opinião Pública", baseando-se no ensaio que, sobre o mesmo tema, acabava de ser publicado em El Espectador Sevillano. À maneira de Rousseau, o articulista rotula a "opinião pública" de "mãe fecunda de heroísmo" e de "força motriz da energia nacional"15. Articula os juízos de interesse geral com as virtudes cívicas que promanam da educação e do direito público e sustenta, seguindo as teses do autor do Contrato Social, que sem o consensus omnium conferido pela opinião pública a sociedade ficaria privada de liberdade e os cidadãos dos seus direitos.

Em outros textos recorre, igualmente, a conceitos de Rousseau, como o de lei, na aceção de emanação da vontade geral, ou o conceito de liberdade, entendida como condição resultante, na sociedade civil, do respeito e da observância da lei, ou seja, como direito de não obedecer senão à norma ditada pela vontade geral. Os redatores do jornal chegam mesmo a citar o Contrato Social, como acontece no artigo em que reproduzem uma passagem do capítulo IX do livro III, referente às características de um bom governo ${ }^{16}$. Porém, também denunciam os excessos de "absoluta liberdade e igualdade" de demagogos como Championet, Marat e Robespierre que instauraram o terror em França e de verdugos das nações da Europa como Napoleão Bonaparte, tomando todos como discípulo de Rousseau e de Robespierre ${ }^{17}$

${ }^{14}$ BOISVERT, Georges - Un pionnier de la propagande liberale au Portugal: João Bernardo da Rocha Loureiro (1778-1853). Paris: F. C. Gulbenkian, 1982, p. 318-319; Cf. Correio da Peninsula, 1809, vol. 1, p. 312.

${ }^{15}$ Correio da Peninsula, 1810, vol. 2, p. 9-14.

${ }^{16}$ Correio da Peninsula, 1809, vol. I, p. 255.

${ }^{17}$ Correio da Peninsula, 1809, vol. 1, p. 182-183. 
A memória dos atropelos governativos, dos tumultos e do terror que marcaram o curso revolucionário em França, é, de resto, recorrentemente evocada, pela propaganda liberal em Portugal, para justificar a assimilação crítica da teoria política de Rousseau. A partir da Declaração dos Direitos do Homem e do Cidadão discute-se a noção de liberdade natural e de liberdade civil e política. Com base na constituição republicana de 1793, questiona-se o alcance do deslocamento da sede soberania, do rei para o povo. No cerne deste debate encontra-se, invariavelmente, Rousseau.

Em 1813, no rescaldo das acaloradas discussões ocorridas nas Cortes de Cádis, Liberato Freire de Carvalho, referindo-se a liberdades, direitos e garantias dos cidadãos, escreve nas páginas do jornal $O$ Investigador Portuguez que "tudo quanto o celebre Rousseau disse no seu discurso sobre a desigualdade dos homens não he mais do que o desafogo de hum philosopho que aborrece a sociedade, cuja necessidade todavia não pode negar. Tudo quanto elle disse e desenvolveo no seu Contacto Social he pela maior parte ociozo, inútil, impraticável ou prejudicial"18.

Este liberal moderado, exilado em Londres, sem pôr em causa a aspiração de perfectibilidade do homem, considerava, todavia, utópica "a reforma geral do género humano". No plano político, a recusa do contrato de constituição da sociedade civil, invalidava a ideia de liberdade recíproca dos indivíduos depositários da soberania popular, organizados em comunidade política e elevados à categoria de cidadãos. O pacto social, ao conferir, artificialmente, direitos iguais a todos e a cada um dos seus membros, tornava legítima a associação e pacífica a sociabilidade. Portanto, para ser livre e viver em paz o homem tinha que estar submetido à lei. A resistência expressa à aceitação destes princípios, de fundo pactual, tinha subentendida a visão histórica e orgânica da sociedade que apontava para o restabelecimento da "liberdade dos antigos" e para a partilha de soberania entre o rei e o povo. Na base deste pressuposto, considera-se "ilusório" e "perigoso" o princípio de que "todo o poder vem do povo". As lições da tradição antiga e moderna, confirmavam que a experiência da tirania dos trinta em Atenas, a anarquia

${ }^{18}$ O Investigador Portuguez em Inglaterra ou Jornal Literario, Politico. Londres, Agosto de 1813, VII, p. 196. 
da Convenção em França e o rastilho das revoluções de independência na América Espanhola tinham em comum a defesa da soberania popular ${ }^{19}$.

A soberania era imprescritível e inalienável, valia como atributo e não como título de propriedade de pessoa ou grupo. Na base desta ideia, os mentores da Revolução de 1820 procuraram, na discussão dos artigos da Constituição de 1822, restringir a omnipotência do poder constituinte e a inviolabilidade do direito de resistência contra a tirania e o arbítrio dos governantes. Apesar de ter sido largamente sustentada pelos sectores moderados, esta prevenção não convenceu a maioria dos constituintes vintistas que, na esteira de Rousseau e, especialmente, de Sièyes, consagram, na Constituição de 1822, o princípio de que "a soberania reside essencialmente em a Nação. Não pode, porém, ser exercitada senão pelos seus representantes legalmente eleitos. Nenhum indivíduo ou corporação exerce autoridade pública que não derive da mesma Nação" (artigo 26).

No fulcro da sociedade política, a soberania popular, mitigada pela exigência moderna da representação - cada deputado, independentemente do seu círculo eleitoral, devia representar toda a nação -, converte-se em reduto do poder constituinte e não se esgota na norma que a constitucionaliza. É impossível não ver esta formulação como um prudente afastamento das teses sustentadas por Rousseau no livro $2^{\circ}$ do Contrato Social. Na verdade, a leitura desta obra vulgarizou-se enormemente, em Portugal, em vésperas da aprovação da Constituição de 1822. Com algum exagero, um contemporâneo, José Acúrsio das Neves, erigiu o Contrato Social em principal oráculo da Assembleia Constituinte, ou melhor, das Cortes Gerais e Extraordinárias das Nação Portuguesa ${ }^{20}$.

\section{Edições, leituras e anotações ao Contrato Social}

Livro de cabeceira para alguns deputados, jornalistas e membros de sociedades patrióticas, porém citado de forma muito parcimoniosa em Cortes

${ }^{19}$ Com mais referências vide MACHADO, Fernando Augusto - Rousseau em Portugal..., cit., p. 446.

${ }^{20}$ NEVES, José Acúrsio das - Cartas de um português aos seus concidadãos sobre diferentes objectos de utilidade geral e individual in Obras Completas de José Acúrsio das Neves. Porto: Edições Afrontamento, s.d., vol. VI, p. 81. 
e na imprensa de opinião ${ }^{21}$, o Contrato Social ou Princípios do Direito Politico conheceu duas traduções em língua portuguesa e, seguramente, três edições distintas, logo a seguir à revolução de 1820. A edição popular saiu primeiramente em fascículos nas páginas do jornal mensal O Compilador, começando a publicar-se em Novembro de 1821. Vendia-se o jornal avulso a 480 réis e a assinatura semestral a 2400 réis. A versão compilada à parte, editada pela tipografia Rollandiana, em 1821, é diferente da que encontramos nas páginas de $O$ Compilador, ou seja, comporta o livro $4^{\circ}$ do Contrato Social, que, dada a suspensão do jornal, em Agosto de 1822, não chegou a publicar-se, integralmente, em fascículos. A tradução portuguesa, provavelmente da autoria do principal redator do referido periódico, José Baptista Gastão, reproduz a versão completa da obra - sem fazer menção ao manuscrito de Genève, revisto por Rousseau - e é anotada, isto é, apresenta cinco preciosos comentários da responsabilidade do tradutor, em notas de roda pé.

No mesmo ano em que correu em Lisboa esta edição, publicou-se em Paris uma outra, também em português, com a chancela da casa Firmino Didot $^{22}$. Destinava-se igualmente ao mercado livreiro nacional e o tradutor, o afrancesado Bento Luís Viana, dedicou a sua versão do Contrato Social a Simão da Rocha Loureiro, familiar do articulista do jornal O Portuguez que se publicava em Londres. Ignoramos a tiragem que tiveram as duas edições de 1821 do Contrato Social, mas admitimos que cada uma não tenha sido inferior a 1500 exemplares.

Em 1823, a Imprensa da Universidade de Coimbra, a pedido do livreiro Jacques António Orcel, imprime 2000 exemplares daquela que foi a $3^{\text {a }}$ edição portuguesa do Contrato Social. O registo do livro de contas das obras impressas com a chancela da Universidade diz respeito ao mês de Abril de $1823^{23}$. Nessa altura, os sinais de colapso do regime liberal eram evidentes e avolumavam os receios de pesadas represálias dos absolutistas. Sobrevindo o golpe contra-revolucionário da Vilafrancada, em finais de Maio desse ano,

${ }^{21}$ PINA, Ana Maria - De Rousseau ao imaginário da Revolução de 1820. Lisboa: INIC, 1988.

${ }^{22}$ OUTEIRINHO, Fernanda - As traduções da obra de Rousseau em Portugal: texto e paratexto. Revista da Faculdade de Letras - Linguas e Literaturas. Vol. XII (1995) 397.

${ }^{23}$ Arquivo da Universidade de Coimbra, Imprensa-Contas das obras dos particulares, liv. 153 , fl. 52. 
é de admitir, dada a inexistência de exemplares desta edição em bibliotecas nacionais, que foram destruídos todos ou quase todos os exemplares então impressos do Contrato Social.

Ora, se este dado novo tem alguma importância, pela negativa, na história da receção da obra de Rousseau em Portugal, mais relevante se afigura, em termos de protocolo de leitura, a primeira tradução anotada da mesma obra. Os comentários e as advertências que pontuam o texto apontam para a articulação possível da teoria política de Jean-Jacques Rousseau com as bases da Constituição de 1822 .

A primeira nota do tradutor, colocada na abertura ao livro $1^{\circ}$ do Contrato Social, remete para a experiência de participação democrática dos cidadãos num "Estado livre", por meio de voto e participação cívica. Os direitos outorgados pela cidade de Genebra aos seus cidadãos davam ao filósofo sobejos motivos "para amar a sua Pátria”. Insinuando inevitáveis diferenças na forma de governo de uma pequena república e de uma monarquia pluricontinental o anotador escreve: "Rousseau aplaudia-se, julgava-se feliz por ter nascido cidadão de um Estado livre, da pequena Republica de Genebra. Com mais razão os actuaes portuguezes de ambos os hemispherios se devem regozijar por verem passar do estado do mais arbitrário despotismo á condição de homens livres, de cidadãos constitucionais, membros da soberania de uma nação respeitável"24. Fica claro que, qualquer que fosse o fim da união civil, a liberdade inalienável dos cidadãos garantia a força e a unidade do Estado, cuja finalidade era a conservação e a prosperidade dos seus membros. O problema estava em encontrar uma forma de associação e de governo que defendesse melhor a união de todas as partes da monarquia. Se, no plano da linguagem política, a sintonia de conceitos é evidente, no campo da teoria política afasta-se a possibilidade de um governo republicano. O modelo das repúblicas independentes da América espanhola é mesmo totalmente silenciado. Em contraponto com a escravização imposta por um

${ }^{24}$ ROUSSEAU, Jean-Jacques - O Contracto Social ou Principios do Direito Politico, traduzido pelos redactores de $O$ Compilador. Lisboa: Typ. Rollandiana, 1821, p. 4. Utilizamos nas notas seguintes esta edição da obra, seguida, sempre que se justifique, da referência às Oeuvres Complètes, Du Contrat Social, vol. III. Paris: Gallimard, Bibliothèque de la Pléiade, 1964. 
governo despótico, as vantagens da monarquia constitucional sobressaem nas duas notas seguintes ${ }^{25}$.

Estas ressalvas não limitam, no essencial, a aceitação da matéria dos dois primeiros livros do Contrato Social, centrados na fundamentação da sociedade civil, na legitimidade da lei e na força da vontade geral. Relembre-se que, segundo Rousseau, as cláusulas de associação visam o bem comum e quando bem compreendidas resumem-se a uma só, a saber: “ a alienação total de cada associado com todos os seus direitos a toda a comunidade. [...] cada um dando-se por inteiro, a condição he igual para todos, e nenhum tem interesse em a tornar onerosa a outros" ${ }^{26}$. Por este meio, a liberdade civil dos indivíduos era constituída por convenção, ou seja, por um ato de reconhecimento explícito que fundava a legitimidade do todo político. Este ato de reconhecimento, exprimindo-se sob a forma de lei, emanava da vontade gera ${ }^{27}$. O compromisso total gerado pela vontade geral dava origem a "um corpo moral e colectivo", cuja unidade e essencialidade não era metafísica ou quimérica mas política. Logo, a isonomia que a lei institui tem o seu fundamento no "eu comum" que sustem o todo soberano. "Pelo que, se, por um lado, o Soberano nascido do contrato, é composto por todos os contratantes e a eles deve a sua existência e realidade, por outro, constitui a condição essencial para que os indivíduos passem da ordem natural, dominada pelo instinto, para a ordem política, salto que só o Soberano, através do Legislador, poderia instaurar e constantemente renovar. Deste modo, a Soberania impõe-se como uma força simultaneamente imanente e transcendente aos poderes que constitui" ${ }^{28}$.

Aceites as premissas que convertiam o contrato em fonte de regulação da sociedade civil, o anotador suscita a clarificação do problema da repre-

${ }^{25}$ ROUSSEAU, Jean-Jacques - O Contracto Social..., cit., p. 6 e 8.

${ }^{26}$ ROUSSEAU, Jean-Jacques - O Contracto Social ..., cit., p. 19. Cf. Oeuvres Complètes, vol. III, Du Contrat Social, liv. 1, VI, p. 360-361.

${ }^{27}$ BERNARDI, Bruno - La fabrique des concepts: recherches sur l'invention conceptuelle chez Rousseau. Paris: Honoré Champion, 2006; SPITZ, Jean-Fabien - La liberté politique. Essai de généalogie conceptuelle. Paris: PUF, col. Léviathan, 1995; DERATHÉ, Robert - Jean-Jacques Rousseau et la science politique de son temps. Paris: J. Vrin, 1995.

${ }^{28}$ CATROGA, Fernando - Em nome da Nação in CATROGA, Fernando e ALMEIDA, Pedro Tavares de (coord.) - Res Publica. Cidadania e representação política em Portugal, 1820-1926. Lisboa: Assembleia da República/Biblioteca Nacional, 2010, p. 26. 
sentação, em termos que se afiguram mais próximos do pensamento de Sieyès. Segundo Rousseau, "a soberania não pode ser representada, pela mesma razão que não pode ser alienada; ella consiste essencialmente na vontade geral, e a vontade não se representa" 29 . Logo, "os deputados do povo não podem por tanto ser seus representantes, eles não são mais que seus procuradores, nada podem concluir definitivamente" ${ }^{30}$. Mais, "no instante em que um povo se dá representantes já não é livre não existe"31. Ora, é precisamente nesta frase do capítulo XV do livro $3^{\circ}$ que o tradutor português coloca uma anotação crítica. Contra a ideia de que o legislador coincide e se identifica com os cidadãos livres da res publica, ou seja, em desabono da unicidade do Estado, sobressai a tese de que nos Estados livres e independentes a autoridade política tem uma base eletiva. Por isso, e em detrimento do modelo das repúblicas antigas, conclui o nosso anotador que "o meio de eleger representantes he uma invenção moderna, não há duvida, mas he elle o único que, nas circunstancias modernas, pôde mais facilmente exibir a maioria da vontade da Nação, isto he a lei: - e o Estado he livre e existe" 32. Esta formulação, herdeira da tradição instaurada pela constituição de $1791\left(\right.$ art. $\left.^{\circ} 3^{\circ}\right)$, consagra o primado da nação sobre o povo e consente, por via indirecta, a representação política de todos os membros da sociedade, de acordo com o conceito de representação nominal defendido por Sieyès no opúsculo Qu'est-ce que le tiers état?

Por último, o comentário aposto ao $4^{\mathrm{o}}$ livro introduz na leitura da obra uma evidente linha de fratura na aperceção sacralizada do poder - que apela à "santificação do contrato social" - e, concomitantemente, na visão do Estado como instância criadora e encarnadora de uma religião civil. Como é sabido, Rousseau defende, em coexistência com outros credos, "uma profissão de fé puramente civil, cujos artigos cumpre ao soberano fixar, não precisamente como dogmas de religião, mas sim como sentimentos de sociabilidade, sem

${ }^{29}$ ROUSSEAU, Jean-Jacques - O Contracto Social..., cit., p. 141. Cf. Oeuvres Complètes, vol. III, Du Contrat Social, liv. 3, XV, p. 429.

${ }^{30}$ ROUSSEAU, Jean-Jacques - O Contracto Social..., cit., p. 141. Cf. Oeuvres Complètes, vol. III, Du Contrat Social, liv. 3, XV, p. 429-430.

${ }^{31}$ ROUSSEAU, Jean-Jacques - O Contracto Social..., cit., p. 143. Cf. Oeuvres Complètes, vol. III, Du Contrat Social, liv. 3, XVI, p. 431.

${ }^{32}$ ROUSSEAU, Jean-Jacques - O Contracto Social..., cit., p. 144. Cf. Oeuvres Complètes, vol. III, Du Contrat Social, liv. 3, XV, p. 431. 
os quaes he impossivel ser bom cidadão"33. Esta profissão de fé civil revestia um carácter coactivo, moldava-se por princípios simples, compagináveis com outras crenças e visava garantir o unanimismo na sociedade política.

Apresentando-se como criação de um Estado aconfessional, esta nova "religião do cidadão" dicotomiza a autonomia do juízo político da função mediadora da igreja ${ }^{34}$. Para chegar a este estádio, Rousseau resume a pluralidade do religioso a três grandes sistemas: a "religião do padre" com "duas legislações, dois chefes e duas pátrias", a terrena e a celestial (o cristianismo histórico); a religião do cidadão que "reúne o culto divino e o amor das leis, fazendo da pátria o objeto de adoração dos cidadãos" (com matriz nas religiões pagãs da Antiguidade); e a religião do homem, interior, "sem templos nem altares" (teísta, deísta e puramente evangélica, etc.). Não sendo nenhuma das religiões consideradas isenta de consequências práticas de monta na ordem política, o cristianismo é particularmente visado na apreciação crítica de Rousseau. Partindo do pressuposto de que "uma sociedade de verdadeiros christãos não seria uma sociedade de homens" 35 , conclui que o cristão é escatologicamente arrastado para fora do mundo. Por outro lado, a sua inserção na vida da igreja é fonte de dissídio, servidão e dependência. E como a religião civil comportava uma moral pública autónoma e pressupunha uma fidelidade à pátria capaz de religar, pelo sentimento, todos os cidadãos, o universalismo cristão podia sempre contender com o patriotismo exigido à conservação do Estado. Enfim, para Rousseau, qualquer que fosse a perspetiva de atuação do cristão na polis, ela afigurava-se perniciosa à unidade social e à homogeneidade política da res publica.

A religião civil apresentava-se assim como síntese superior de uma crença supletiva que favorecia a sociabilidade na polis e gravava, na consciência e

${ }^{33}$ ROUSSEAU, Jean-Jacques - O Contracto Social..., cit., p. 201. Cf. Oeuvres Complètes, vol. III, Du Contrat Social, liv. 4, VIII, p. 468.

${ }^{34}$ RIZZI, L. - Religione civile e laicità in Rousseau. Il Politico. Revista Italiana de Scienze Politiche, 1996, anno LXI, 3, p. 443-462. Cf. WATERLOT, Gislain - Roussseau. Religion et politique. Paris: PUF, 2004; BERNARDI, Bruno et al. (dir.) - Religion, Liberté, Justice: un commentaire des Lettres écrits de la Montagne de J.-J. Rousseau. Paris: Vrin, 2005.

${ }^{35}$ ROUSSEAU, Jean-Jacques - O Contracto Social ...cit., p. 197. Cf. Oeuvres Complètes, vol. III, Du Contrat Social, liv. 4, VIII, p. 465. 
no coração de cada um, os deveres do cidadão ${ }^{36}$. As suas regas eram claras e simples e os seus reduzidos dogmas fixados de acordo com a vontade geral. No essencial, limitavam-se a pressupor a existência de uma divindade providente ou de um princípio de criação inteligente e benfazejo, a proclamar a "santidade do contrato social" e das leis e a zelar pela felicidade dos justos e pela condenação dos maus e dos criminosos. Pela negativa, a religião civil recusa somente a intolerância.

Em face deste corpo de princípios avoluma-se a perplexidade do tradutor e insinuam-se as suas reservas aos capítulos do livro $4^{\circ}$ do Contrato Social dedicados à questão da tolerância, do direito e da utilidade da religião num Estado soberano e livre. Compreende-se. A abertura crítica à "religião do cidadão" implicava a defesa de um laço estreito entre a religião civil (rejeitada) e o soberano. Mas, do mesmo modo que se recusava a aliança entre a laicidade da lei, a sacralidade do Estado e a fé civil dos cidadãos, procurava-se reforçar o lado prático e moral da adesão afetiva à causa liberal, através do conceito de opinião pública. Por isso, na antevisão do artigo $17^{\circ} \mathrm{da}$ Constituição de 1822 que consagra, no quadro da monarquia constitucional portuguesa, "a religião católica, apostólica romana como a religião da nação" e adivinhando a resistência da igreja e, mais ainda, as possíveis divisões entre conservadores e liberais a respeito da liberdade religiosa e de cultos, o(s) tradutore(s) lavra(m) a seguinte advertência: "O capítulo do Contrato Social sobre Religião Civil não foi supprimido em nossa tradução, para que toda a obra apparecesse completamente traduzida. Não nos atrevemos a fazer-lhe notas, porque medimos a distância que vai de nós a tão profundo autor; e porque nos convencemos que algumas doutrinas religiosas que ela encerra, e muitas das quaes nós desaprovamos, farião nos ânimos dos religiosos portuguezes tamanha sensação como a que experimentámos; isto é, que lhes havião de interessar as coisas de razão, julgar as de opinião, e conservar-se inabaláveis sobre as da verdadeira fé" 37 .

Este breve comentário reflete o apego à liberdade e à tolerância por parte de um entusiasta da ordem liberal e, acima de tudo, torna público o respeito

\footnotetext{
${ }^{36}$ CATROGA, Fernando - Entre Deuses e Césares. Secularização, laicidade e religião civil. Coimbra: Almedina, 2006, p. 109-127.

${ }^{37}$ ROUSSEAU, Jean-Jacques - O Contracto Social..., cit., p. 204.
} 
e a admiração pela obra política do pensador genebrino. Mas também vem confirmar a fraqueza da auto-suficiência racional da teoria política de Rousseau, nem sempre adaptável às circunstâncias históricas que ditaram a vulgarização da sua linguagem política.

\section{A dimensão demopédica do Contrato Social: sociabilidade política e catecismos do cidadão}

Ainda assim, das largas centenas de escritos de atualidade política que contribuíram para colocar na ordem do dia os conceitos de liberdade, igualdade, vontade geral, opinião pública e soberania nacional e que se destinavam convencer o povo das virtudes de um governo legítimo, de base constitucional, os "catecismos políticos", os "catecismos do cidadão" e os "catecismos constitucionais", muito em voga neste período, foram igualmente concebidos sob a influência direta e indireta de Rousseau ${ }^{38}$. Tornavam pregnante e instrutivo o credo político liberal. Disseminavam, recorrendo ao formalismo do ensino religioso, os deveres do cidadão e os sagrados princípios da Constituição de 1822. Enfim, tomavam de empréstimo o espírito da religião civil de Rousseau, dando espaço à hierofania política, sem ousarem suplantar o papel da igreja católica na sociedade portuguesa.

Dos vários títulos então publicados, merecem especial relevo: o Catehecismo Polytico Constitucional, regulado segundo a Constituição Portugueza (1823) adaptado de um catecismo espanhol, conforme esclarece, no prólogo, o tradutor António Herculano Debonis. A fidelidade ao pensamento de Rousseau é explicitamente afirmada no jogo de perguntas e respostas sobre os conceitos de "liberdade", "lei", "povo" e "instrução pública". Se algumas passagens do catecismo são transcrições do Contrato Social, em outras partes do texto retoma-se o acento republicano e democrático do genebrino como o comprova a seguinte afirmação radical: "o rei é um cidadão como os

\footnotetext{
${ }^{38}$ VARGUES, Isabel Nobre - A linguagem religiosa e a propaganda política (1820-1823). Revista de História das Ideias. 9 (1987) 452-479; VARGUES, Isabel Nobre A fé política liberal. Revista de História das Ideias. 11 (1989) 277-285.
} 
mais, que recebe a sua auctoridade da Nação" ${ }^{39}$. Idêntica opinião transmite o Manual Politico do Cidadão Constitucional (1820), esclarecendo que "o governo democrático ou republicano he aquelle em que o povo he livre e se governa a si mesmo pelos seus magistrados, que elle mesmo elege" As vantagens desta forma de governo são, de resto, facilmente compreensíveis: - "sendo fundada no amor da liberdade, e igualdade, eleva os cidadãos e as virtudes heroicas e acende nas suas almas o mais vivo patriotismo" 40 . Porém, por mais perfeito que fosse, teoricamente, o modelo das modernas repúblicas nascidas depois da Revolução Francesa, os grandes Estados dificilmente consentiam, sob pena de rebelião, que o povo participasse diretamente do tribunal supremo e da sanção de todas as leis.

Feita a ressalva, a dimensão demopédica rousseauniana ressurge no Cahecismo Politico do Cidadão Portuguez (1823), da autoria de Rodrigo Ferreira da Costa. Apostado em demonstrar a justeza da formação da sociedade civil e a legitimidade do governo, este autor demarca o seu catecismo da esfera sobrenatural ou transcendente, considerando-o a meio caminho daquilo a que chama um "catecismo científico". Destina assim a exposição dos direitos e obrigações do homem natural e social e dos princípios da ordem política à educação cívica da mocidade portuguesa. Não deixa de sacralizar o estatuto do indivíduo como cidadão, mas faz coexistir este sentimento com a necessidade de uma educação pública que fortaleça a identidade política da nação. Neste ponto, à pergunta: “Como se illustra a vontade geral?" Responde o autor do catecismo: “Pela deliberação e discussão pública dos negócios comuns. E esta controvérsia só pode ser promovida pela liberdade de pensar, falar, escrever, e imprimir. A tolerância das opiniões he o foco da ilustração" ${ }^{41}$. Por meio da livre expressão das ideias, a "opinião pública" - segundo Rousseau - julga os costumes e os propósitos comuns dos cidadãos, gerando o consenso necessário à manifestação da vontade geral. Irmãs gémeas na vida social, "l'opinion publique est à la

${ }^{39}$ Catehecismo Polytico Constitucional, regulado segundo a Constituição Portugueza, por A. H. D., $2^{\mathrm{a}}$ edição mais correcta e augmentada. Lisboa: Typ. Rollandiana, 1823, p. 17.

${ }^{40}$ Manual Politico do Cidadão Constitucional. Lisboa: Imprensa da Viuva Neves e Filhos, 1820, p. 10.

${ }^{41}$ COSTA, Rodrigo Ferreira da - Cahecismo Politico do Cidadão Portuguez ou Exposição dos direitos e obrigações do homem natural e social. Lisboa: Imprensa Nacional, 1823, p. 90 . 
volonte générale ce que le sentiment intérieur est á la raison: sa fonction n'est pas de faire voir au peuple son bien mais de lui faire aimer" ${ }^{\prime \prime 2}$.

Ora levar os cidadãos a amarem a lei e educá-los para servirem a causa pública era a finalidade principal dos catecismos políticos. Neles, o patriotismo, à semelhança do que defendera Rousseau, tem lugar destacado, pois o amor à pátria era "o primeiro dever do cidadão" e o "princípio gerador de todas as virtudes sociaes". "Sem amor à patria dissolve-se o Estado, e morre o corpo político"43

Em suma: a prática da "cidadania virtuosa", assente na liberdade individual, fazia da salvaguarda deste direito uma obrigação totalitária, apontando para um terrível compromisso de dependência do cidadão em relação ao Estado e imponho-lhe, no limite, o sacrifício da vida em prol da defesa da pátria. Este desenvolvimento da teoria política de Rousseau, particularmente explorado pela literatura propagandística dos primeiros catecismos revolucionários em Portugal, contribuiu, em termos práticos, para fixar a linguagem da Revolução e definir a radicalidade do combate liberal em defesa da causa pública.

${ }^{42}$ BERNARDI, Bruno - Rousseau et la généalogie du concept d'opinion publique in O'DEA, Michael (dir.) - Jean-Jacques en 2012. Pusqu'enfin mon nom doit vivre. SVEC, 2012-1, p. 117.

${ }^{43}$ COSTA, Rodrigo Ferreira da - Cahecismo Politico do Cidadão Portuguez..., cit., p. 112. 